\title{
Research on Career Planning and Development of College Counselors
}

\author{
Rui Tang \\ College of Vanadium and Titaniumg, Panzhihua University, Panzhihua, Sichuan, China \\ 904200315@qq.com
}

Keywords: College Counselors, Career Planning, Team Construction

\begin{abstract}
The construction of college counselors is an important means to strengthen and improve the ideological and political education of college students. It has a special mission and is of great significance. The career development plan of the tutor is closely related to the professionalization and professionalism of this team. Based on the perspective of career planning, this article analyzes the status quo of college counselor team construction, the problems in their career development and their countermeasures, and puts forward the implementation path of college counselors career development plan and suggestions and countermeasures to strengthen the construction of counselors team.
\end{abstract}

\section{Introduction}

College counselors are an important force for college teachers, and also an indispensable link in the construction of college teachers. They have important and special missions in the cultivation of higher education personnel, scientific research, social services, and cultural heritage and innovation. The career development status of the counselor will directly affect the stability and continuity of the counselor team construction as well as the professional and professional development level [1]. The importance of the career development and team building of the counselor is self-evident. The development of the counselor's career should be based on the organic unity of self-value and social value, and improve the dual drivers of self development needs and social recognition. Under the historical conditions, the research on career development of counselors has important practical significance and practical value.

\section{The status quo and problems of counselors}

At present, the stability of the college counselors team is not strong, the post changes are more frequent, the social public to the counselor's professional identity is low, the counselor's career tenure system development policy guidance is not strong, the lack of professional development impetus and other contradictions are increasingly prominent, certain To a limited extent, it restricts and limits the construction and individual development of college counselors. Under the conditions of the new period, college counselors should review their occupations and position them scientifically, and profoundly analyze various unfavorable factors that restrict the career development of counselors. Based on the explanation of the basic rules of the career development and personal growth of counselors, they are analyzed and proposed. However, in the actual work, there are many problems in the development of the counselor team, although to a certain degree, the policy environment and operability of the college counselor for the lifelong career are guaranteed. However, from the actual situation, the occupational awareness of the counselor is not comprehensive, college counselors are faced with the contradiction between higher professional requirements and inadequate professionalism. The contradiction between transitional career orientation and lifelong vocational requirements is very prominent. These make the development of counselors contingent on a favorable policy environment.The main problems that exist are mainly reflected in the following three aspects. 


\subsection{Inadequate institutional mechanisms for career development}

The institutional mechanism of the career development of college counselors refers to the general term for the education authorities responsible for the construction of college counselors' team to promote the career development of college counselors in terms of policies, rules and regulations, platform construction, and actual operations. At present, the relevant management mechanism for the career development of counselors is still not perfect, mainly reflected in: first, the implementation of superior policies is not in place, and further supervision and supervision are needed. Some provinces, municipalities, and colleges have not yet formed a detailed and highly operational plan for the construction of college counselors. They have not implemented the contents of the documents clearly defined by the Ministry of Education and have not implemented it properly. Some colleges and universities have not reached the required standards for the number of counselors;. Second, the path of career development is not smooth, and professional construction needs to be improved. Professional access mechanisms, performance evaluation standards, growth and development environment and other industrial systems of the counselor team are incompatible with the team construction, leading to the existence of unclear positioning of the counselor and job responsibilities. There are a lot of real problems that are unclear and the business is not professional. Some colleges and universities have not defined the path of career development for two-way promotion and two-way development in terms of job title appraisal, job promotion, etc. The counselor's scientific research platform is still relatively small, the subject support is not enough, and the research funding is insufficient.

\subsection{Indigenous motivation for individual career development is insufficient}

From the perspective of college counselors, the lack of internal motivation will directly constrain the planning and implementation of careers. The professional emotions of college counselors can come from three aspects: professional identity, sense of honor, and professional dedication. The core elements of professional emotions are: the sense of professional honour is influenced by both the external environment and its own experience. The formation of professional dedication of college counselors requires long-term work practices and positive feedback to complete, and needs to be established on the basis of good professional identity and professional honour. However, with the development of professional career, the professional identity of college counselors begins to subside, accompanied by the status of professional honour is not strong, and their professional dedication is also difficult to establish in time. Unsteady professional emotions will develop further negatively The professional emotions, which in turn produce negative and negative professional behaviors, make the job only as a simple job, lacking a positive attitude, upward motivation, and professional responsibility. This negative professional emotion causes the college counselor to create some sort of job with their own work. The degree of divergence and the impact on the professional environment. Therefore, in practical work, how to cultivate the professionalism of college counselors, make them positively identify with their professions, enhance their sense of professional responsibility, invest professional activities in an active state, and develop their careers better.

\subsection{The humanistic environment for career development needs to be optimized}

The humanistic environment of college counselors' career development has exerted an important influence on them. The current humanistic and social environment for college counselors' career development needs to be further strengthened and optimized. There are several prejudicial views: first, many people question the necessity of the existence of college counselors occupational groups, and from the roots, they deny the rationality of the university's ideological and political education work, and then deny the existence of college counselors as a professional group. Second, some people are skeptical about the career development of college counselors. It is believed that the counselor only needs to do a good job in the daily affairs of the student's daily education management, and does not need to make reasonable 
planning and design of his career development. In particular, the development direction of specialization and professionalization is not suitable for the affairs of college counselors. Thirdly, there are individuals with low ideological consciousness, limited business skills, strict work discipline, and lack of professional ethics in the college counselor team. The overall reputation of the counselor team is affected to varying degrees, resulting in the external to college counselors. A professional's cognition and evaluation are mixed and unfair. The subjective comparison of the counselor's occupation with other administrators, professional teachers, etc. is simply done, and the professional value of college counselors is reduced. These adverse external evaluations affect the college counselors' own positive health value and occupational emotions, which have a certain negative impact, and are also an important external factor affecting the career development of college counselors.

\section{The counselor team career development breakthrough path}

Guided by the important ideas of following the professionalization and professionalization of college counselors, in terms of professional career development of college counselors, the multi-channel diversification of career development of college counselors has been achieved through professional training [2]. The career development path should form scientific and rational construction ideas and implementation methods from the three dimensions of macro-architecture, deepening of practice, and micro-operation.

First, scientifically promote the process of specialization and professionalization at the macroarchitecture level. At the macro level, it is necessary to grasp the progress of career development of college counselors in a scientific and orderly manner. It is necessary to clearly select the criteria for recruiting people and put a good entrance into the profession. In the aspects of political quality, academic background, knowledge ability, etc., specific and explicit requirements for rigid conditions are put forward. Choose outstanding graduates who have professional background in industry, good organizational management and coordination skills, and strong language and written skills, and have received systematic and professional training, to ensure the continuous and stable and coordinated development of the outstanding talent team of the counselors. The second is to build a scientific and rational training and training system. We must not only train our knowledge and skills, but also pay attention to the promotion of academic degree, as well as daily targeted selection, training, and ability enhancement. It is necessary to unblock the path of professional ability enhancement and build a platform for the development and growth of counselors. The third is to establish a scientific and reasonable title, a structure of academic qualifications, and focus on building a scientific and reasonable talent system for the professional development of counselors, and vigorously strengthen the professionalization and professional development of this team.

Second, the level of deepening in practice has shifted from generalization to personalized development. The institutionalized background of college counselors makes the phenomenon of modelling and stereotyping existing, which restricts the development of personality of college counselors. First, we should pay attention to the growth of college counselors. Schools should establish a career development platform for counselors, incorporate the cultivation of business skills into the overall planning and construction goals of the overall teacher team construction, and at the same time pay attention to individualized needs and determine their professional development. The development path of job responsibilities, growth goals, etc., enables counselors to grow in terms of promotion, promotion of titles, etc., and increase their sense of honor and belonging, so that the work of the counselor can truly become a long-term continuous work. And career. On the other hand, we pay attention to solving practical problems and ideological problems faced by counselors, concern about the daily work of the counselor, leisure life and learning progress, strengthen the humanistic care for counselors, and understand the real 
development needs and emotions of counselors. Needs, gradually establish an emotional support system for the counselor's daily work and study and life, and solve specific practical problems in development.

Finally, in the micro operation level, it is necessary to grasp the actual growth needs of the counselors. The first is the need for personal growth and the second is the need for development of the times. In general, the biggest problem faced by college counselors today is how the level of professionalism and professionalism can be promoted and promoted mutually. In the specific operations, it is through "problem orientation" that the practical problems encountered by counselors in their work are taken as the materials and topics for in-depth research, starting with the problems and guiding them to focus on the hot issues and reality in the current ideological and political education for college students. Problems, build a professional research platform, focus on training and raising the counselor's ability to solve practical problems, form a practical chain of "discovery problems - research topics - to solve problems" [3]. In addition, the counselor must also grasp their basic position in the school environment, closely integrate the ideological education in the second class with the teaching work in the first class, and fully promote the growth of the students.

\section{Reflections on strengthening the construction of counselors}

The construction of a highly capable and effective counselor team with strong political skills, good style, and excellent business skills is of utmost importance in strengthening and improving the ideological and political education of college students in the new period, and fully grasps and recognizes the role positioning features of college counselors in the new period. Under the vision of professional career development planning, efforts are being made to strengthen the construction of counselors, which can be promoted and gradually implemented from three aspects: the occupational function orientation, work management model, and basic quality requirements [4].

First, from the perspective of the vocational function of college counselors, the counselor should not only bear the responsibility of imparting knowledge, but also be the guide and leading person for student growth. He is both a good teacher and a friendly friend, and fully respects the university student's dominant position. Under the premise of giving full play to the leading and guiding nature of college counselors, we will guide and guide students in their values, lifestyles, and growth, etc. in the entire process of training, and give full play to the doubts of the teaching profession. "Life Tutor" plays an important role.

The second is that in terms of the management methods of college counselors, college counselors must undertake the exchange of information, but also conduct teacher-student equality communication and dialogue. College counselors face the two major tasks of management and education. In the actual work process, some counselors have a single mode of work that focuses on management. The general performance is as follows: one-way information transmission is responsible for issuing various instructions to make students struggling to cope with, and is in their strict control. The subject status of students has not been fully respected and embodied. The mode of work should be changed from "oneway unilateral transmission" to "two-way equal exchange". Teachers and students should fully interact and establish a platform for exchanges and dialogues, communicate on an equal footing, and understand each other so that they can effectively play their part. The counselor serves as an important role for university students' "intimate friends".

Thirdly, in terms of the basic professional qualities of college counselors, college counselors are not only copying and accumulating business knowledge, but also inheriting and transforming. In the new historical period, the professionalization and professionalization of the coaching staff has become a general trend. College counselors not only need to do well in business affairs such as education management services, but also need to continuously improve their professional quality and professional 
ability. After the counselor fully digests and absorbs the documents and directives at various levels, he will guide the students to grow into talents based on actual guidance. Students will be taught according to their actual conditions and will be educated according to the actual situation.

At present, the construction of the college counselors team is at a critical node. The construction and development of this team will have a significant and far-reaching historical impact on the Litershu people's higher education. With the continuous expansion of the scale of higher education in our country and the continuous improvement of the quality of personnel training, and the transformation of higher education from "elite education" to "popular education", new situations and problems faced by the construction of college counselors are also becoming more complex. The good career development planning of the staff is not only a practical need for cultivating both talented and talented, red, specialized, and full-grown students, but also an important way and an effective vehicle for improving the pertinence and effectiveness of the ideological and political education of college students. The counselor's own comprehensive development and the inevitable requirements of continuous growth and progress.

\section{References}

[1] Liu Lifang. Career Planning-Based Professional Development Of Counselors In Higher Vocational Colleges [j]. Journal Of Jiamusi Vocational College, 2015 (10): 6-7.

[2] Wang Xiu-Yong. Research On Career Planning And Professional Ability Improvement Of College Counselors [j]. Journal Of Huaqiao University, China, 2016, (03): 126-133.

[3] Cao Weiwei. Research On Career Development Of College Counselors [m]. Dissertation Thesis Of Northeast Normal University, 2017: 68-69.

[4] Zhai Ming. New Challenges And New Tasks Faced By Professionalization And Professionalization Of College Counsellors [j]. Ideological And Theoretical Education, 2016. (08): 22-25. 